

\section{DISCLAIMER}

This report was prepared as an account of work sponsored by an agency of the United States Government. Neither the United States Government nor any agency Thereof, nor any of their employees, makes any warranty, express or implied, or assumes any legal liability or responsibility for the accuracy, completeness, or usefulness of any information, apparatus, product, or process disclosed, or represents that its use would not infringe privately owned rights. Reference herein to any specific commercial product, process, or service by trade name, trademark, manufacturer, or otherwise does not necessarily constitute or imply its endorsement, recommendation, or favoring by the United States Government or any agency thereof. The views and opinions of authors expressed herein do not necessarily state or reflect those of the United States Government or any agency thereof. 


\section{DISCLAIMER}

Portions of this document may be illegible in electronic image products. Images are produced from the best available original document. 


\title{
CONTROL DRUM BOW TESTS
}

(EML-48)

\author{
Westinghouse Electric Corporation \\ Astronuclear Laboratory \\ P. O. Box 10864 \\ Pittsburgh, Pennsylvania 15236
}

PREPARED BY:

A. PI. Kallin

I. N. Kallin

Support Structure \& Cryogenic Experiments
NOTICE

This repors was prepared as an account of work sponsored by the United States Government. Neither the United States nor the Unted States Atomic Energ Commission, nor any of their employees, nor any of their contractors, subcontractors, or their employees, makes any warranty, express or 1 mplied, or assumes any legal liability or responsibility for the accuracy, completeness or usefulness of any information, apparatus, product or process disclosed, or Eepresents that its use would not infringe privately owned rights.

\section{APPROVED BY:}

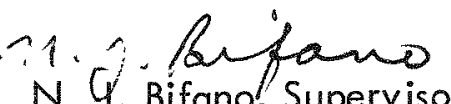

N.G. Bifano, Supervisor

Support Structure \& Cryogenic Experiments

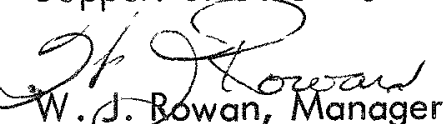

Engineering Mechanics

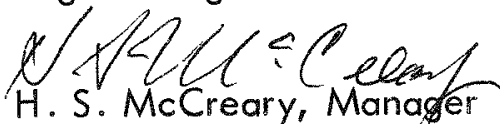

Experimental Engineefing<smiles>c1ccc(C2CCCC2)cc1</smiles><smiles>C1=CCCCC1</smiles><smiles>C1=CC1</smiles>

W. G. Roman Manager

Reactor Engineering, NERVA Project

$/$ fep

INFORMATION CATEGORY

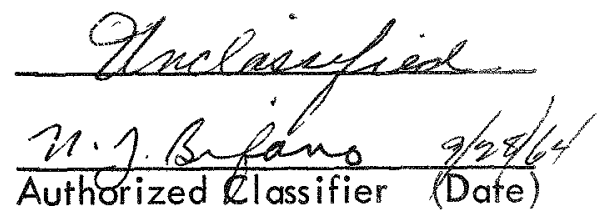




\section{TABLE OF CONTENTS}

Page

Abstract

Background

Conclusions

Test Equipment and Procedure

Results

Figures, Photographs and Graphs 2 5 
ABSTRACT

A series of tests were run which simulated the thermal shock on a control drum during gaseous flow reactor startup and measured the distortion (thermal bow) resulting from this shock. A number of material temperatures within the drum were also measured in order to aid in correlating this data with reactor analys is and test results. The highest bow measured during these tests was $0.038 \mathrm{in}$, and this resulted from a simulated full reactor $5.0 \mathrm{lb} / \mathrm{sec}^{2} \mathrm{ramp}$ (maintained for $5 \mathrm{sec}$ ). Measurement showed that the drum was initially misaligned by $0.0025 \mathrm{in}$. in the opposite direction, so the actual thermal bow was $0.038 \mathrm{in}$. plus $0.0025 \mathrm{in}$, or $0.0405 \mathrm{in}$.

\section{BACKGROUND}

During NRX-Al reactor startup, high control drum torques were observed. There was evidence to indicate that these torques were due to bowing of the control drums causing interference at the bore of the sector (see TME-745). A certain amount of bow during startup would be expected since the drum has a cooling passage system which is designed to remove the large heat flux generated in the control plate region at full power. During startup, the power level is low, but since the flow passages are the same, a large flow of coolant gas occurs on the side of the drum which holds the control plate. This chills the beryllium material adjacent to the control plate passage causing it to contract more than the material across the drum diameter from the plate where the low gas flow causes the temperature to stay nearer room temperature. This temperature gradient causes the drum to bow. After the Al tests, it was decided to measure the bow under various simulated startup ramp conditions and carry out the tests on a single control drum at WANL in order to isolate the test variables. 


\section{CONCLUSIONS}

1. For full reactor gaseous inlet flow ramps of less than $5.0 \mathrm{lb} / \mathrm{sec}^{2}$, and for a control drum initially at room temperature, the startup control drum thermal bow should be less than about J.34) in.

2. If the maximum $\Delta T$ across the center of a control drum during startup is known, the thermal bow can be estimated within $\pm_{2}, 004$ using the test data presented herein.

3. In order to be most effective in reducing bow, prechill flows of $2.0 \mathrm{lb} / \mathrm{sec}$ at about $200^{\circ} \mathrm{R}$ should be continued for not less than 60 sec.

\section{TEST EQUIPMENT AND PROCEDURE}

The flow system is shown schematically in Figure 1. Gaseous helium is drawn from a large truck of 2400 psi and piped to a liquid nitrogen cooled heat exchanger (see Figure 2), where a manually operated valve is used to avoid overpressuring the heat exchanger tubing. Safety relief valves for the heat exchanger fubing are set at $1270 \mathrm{psi}$. The heat exchanger cooling coils are immersed in liquid nitrogen for the tests. A very large cooling coil surface is necessary, not for gaseous helium-to-copper heat transfer, but for copper-to-boiling liquid nitrogen conduction where the heat transfer is very poor.

Downstream of the heat exchanger is another manually operated valve, this valve being used to control the flow through the test chamber. The operator of this valve controls the flow ramp by varying the valve opening so that the system outlet pressure follows a predefermined pressure-time curve on an electronic $X-Y$ plotter. The curve is computed before each test using previous test results to arrive at the curve desired. The flow ramps attempted were all straight line functions and the flow rate vs time curves presented under "Results" indicates the degree of control achieved. 
From the flow control valve, the helium was piped to the test chamber. The chamber appears in the drawing shown in Figure 17. During the later test runs, this piping was prechilled by allowing cold flow to escape through the bleed valve at the bottom of the test chamber. This practice is indicated in the test results by initially lower inlet gas temperatures. Prior to the start of each test, this bleed valve was closed and a plug, which had been placed in the flow measuring nozzle downstream of the test chamber, was removed. The flow measuring nozzle has a short rounded entrance orifice; and during practially all of the flow time, it was run choked.

In order to determine the gas mass flow required to simulate a given "Full Reactor" Flow Rate:, the fraction of the reactor hydrogen flow going through and around the control drum was multiplied by a hydrogen to helium gas conversion factor of about 2.6 , depending on the temperatures of the gases.

The flow passages inside the test chamber were insulated using wood, and the outer volumes where instrumentation was located were dead-ended so that all the flow exiting from the chamber had to go through the control drum passages (see Figure 3). Pieces of wood were machined to fit most of the empty volume in the test chamber in order to minimize the gas plenum in the flow system.

During the testing, the control drum was rotated about $180^{\circ}$ back and forth from the ${ }^{18} \theta=0^{11}$ position. The speed was about $180^{\circ} / \mathrm{sec}$. Strain gaged beams made of titanium were mounted as shown in Figure 17 in order to measure the bow of the drum. Each transducer was calibrated in place. The temperature effect on sensitivity was measured and found to be negligible (less than $5 \%$ ). The bow values in the test results were all obtained from the same transducer which was mounted at $\theta=90^{\circ}$ at the center station of the drum. Other transducers gave about the same magnitude of deflection. This procedure of measuring bow while the control drum is rotating provides a means of measurement with respect to the drum bearings" centerline instead of with respect to the transducer base. 
The necessary assumption is that the transducer base does not move (i.e., the fitanium supporting barrel does not bow) during the one second the control drum takes to rotate. The transducer base was estimated to move less than 0.001 in. per sec. The transducer recorder gives an approximate sine wave trace, the peak-to-peak measurement being the double amplitude or "full indicator reading" of the bow. In the results, the single amplitude of the bow is reported.

Gas pressures and temperatures were measured at the flow measuring nozzle mentioned above $e_{g}$ and also at the piping about three feet upstream of the control drum entrance. Copper-constantan $(\mathrm{Cu}-\mathrm{Con})$ thermocouples were used throughout the test system. The pressure transducers were bourdon type, and they were calibrated in place prior to the test.

About 47 thermocouples were installed in the beryllium drum as shown in Figure 17. Precision thermocouple wire was used and the welded beads were inserted in small holes and potted in place with a mixture of $35 \%$ fine silver powder and $65 \%$ GA-5 epoxy cement. This method had been found to be very reliable and very fast acting. When used with lightbeam galvanometer recorders, it is estimated that the time constant of this temperature measurement is less than $0.10 \mathrm{sec}$.

The thermocouple wires were carried down the length of the drum in specially machined grooves as shown in Figure 17. They were then bundled into a pigtail and carried out through the hole at the center of the drum nozzle end bearing shaft. A loop of the pigtail was left slack to allow flexibility when the drum was rotated. In order to compensate for blockage of the hole through the bearing shaft, the hole was bored out to a larger diameter. The pigtail was then carried up through the insulation around the drum support barrel and the individual thermocouple wires were passed through the pressure vessel vio "Conax" fittings. 
The drum rotation was accomplished by using a reversible electric motor connected through a 60:1 speed reducer and a pair of position limit switches at the drum actuator shaft. The motor uses an electrically operated brake to achieve very fast reversal of rotation. In order to measure drum frictional torque, a short section of the drum actuator shaft was machined down to a diameter which would be more highly stressed, and then instrumented with resistance wire strain gages to form a torque transducer. The strain gage leads were provided with a coil of slack wire, and then carried out of the test chamber using "Conax" fittings. The penetration of the torque shaft through the test chamber wall without gas leakage was accomplished by using two bellows type face seals. The seals are pressure loaded and utilize a rubbing surface of stainless steel against graphite.

\section{RESULTS}

The major test results are presented in Figures 5 through 16. All flow rates reported are simulated full reactor flow rates. The gas temperatures into and out of the test chamber are shown, as are the bow (except for Run 2), the maximum temperature difference across the drum at the center station, and the flow rate. For some of the runs, the piping leading to the test chamber was not prechilled; and this is indicated by higher gas inlet temperatures at the start of the runs. The torque traces were readable for only three runs due to electronic noise in the recording equipment and lead wire damage during the runs. A curve showing the torques measured in Run 2 appears in Figure 6. Accurate bow data was not obtained in the first three runs because the drum was not rotated $180^{\circ}$, and the bowing of the structure to which the transducers were mounted caused inconsistencies in the data. A typical plot of material temperatures measured during the runs is given in Figure 1.4. The remainder of the test data obtained is presented in an internal report. 
A short description of the data obtained in each run follows:

RUN 1

The flow ramp was about $1.7 \mathrm{lb} / \mathrm{sec}^{2}$ for five seconds followed by $30 \mathrm{sec}$ of steady flow at $7.5 \mathrm{lb} / \mathrm{sec}$. The piping was not prechilled and the inlet flow cooled down slowly. The $\Delta T$ across the drum was about $140^{\circ} R$, and the estimated bow (not measured) from Figure 16 is about $0.031 \mathrm{in}$. The results of the run were very similar to those for Run 2 .

\section{RUN 2}

The flow ramp was about $2.0 \mathrm{lb} / \mathrm{sec}^{2}$ for five seconds followed by a slightly decreasing flow of about $10 \mathrm{lb} / \mathrm{sec}$ for $35 \mathrm{sec}$ (see Figure 5). The inlet piping was not prechilled for this run. The maximum $\Delta T$ across the durm was about $144^{\circ} \mathrm{R}$, and the estimated bow, from Figure 16, is about $0.031 \mathrm{in}$. Figure 6 shows drum torque, pressure drop and $\Delta T$ all plotted versus time. This curve attempts to correlate torque with either $\Delta \mathrm{P}$ or $\Delta \mathrm{T}$, however it appears that no simple relation exists. The torque plotted is the difference be between the measured torque and the torque measured before the run started. The initial torque was about $120 \mathrm{in}$.- $\mathrm{lb}$ and was due mostly to the friction drag of the spring-loaded deflection transducers. It is seen from Figure 6 that substantial torque is still required to turn the control drum after the pressure drop has gone to zero.

RUN 3

The flow ramp was about $2.2 \mathrm{lb} / \mathrm{sec}^{2}$ for six seconds followed by a drop-off to a flow of $9.6 \mathrm{lb} / \mathrm{sec}$ in another $32 \mathrm{sec}$. The maximum $\Delta T$ was $157^{\circ} \mathrm{R}$, and the estimated bow (using Figure 16) is 0.036 in. The results of the run were very similar to those for Run 4.

\section{RUN 4}

The flow ramp was about $2.0 \mathrm{lb} / \mathrm{sec}^{2}$ for six seconds followed by a drop-off to a flow of $7.8 \mathrm{lb} / \mathrm{sec}$ in another $28 \mathrm{sec}$ (see Figure 7). The maximum $\Delta T$ was about $153^{\circ} \mathrm{R}$ giving a maximum bow of 0.034 in. 


\section{RUN 5}

The flow came up to about $5 \mathrm{lb} / \mathrm{sec}$ in $1 \mathrm{sec}$ and then varied linearly at about $0.95 \mathrm{lb} / \mathrm{sec}^{2}$ for $16 \mathrm{sec}$ (see Figure 8). The flow then continued to rise at a reduced rate, reaching $24.5 \mathrm{lb} / \mathrm{sec}$ at $t=25 \mathrm{sec}$. The maximum bow was measured and found to be $0.031 \mathrm{in}$. The maximum $\Delta T$ was $145^{\circ} \mathrm{R}$. For this run, thermocouple No. $3 \mathrm{~L}$, usually used in computing $\Delta T_{g}$ did not function properly, but its temperature was estimated from other thermocouple readings. From Figure 8 , it is seen that drum bow and $\Delta T$ across the drum at Station 26 are very similar functions. Both functions start from zero and both return to zero at about $t=31 \mathrm{sec}$. The maximum bow occurs only about three seconds before the maximum $\Delta T$. This similarity persists to some degree in all the other runs.

RUN 6

The flow ramp is about $5.5 \mathrm{lb} / \mathrm{sec}^{2}$ for $5 \mathrm{sec}$, followed by a steady flow of about $27.5 \mathrm{lb} / \mathrm{sec}$ for $13 \mathrm{sec}$ (see Figure 9). The inlet piping was not prechilled, and the gas temperature flowing into the test chamber was $440^{\circ} \mathrm{R}$ at time zero, and $150^{\circ} \mathrm{R}$ after $10 \mathrm{sec}$. The maximum $\Delta T$ across the drum was $125^{\circ} \mathrm{R}$ and the maximum bow was $0.026 \mathrm{in}$.

RUN 7

For this run, a steady prechill flow of $2.0 \mathrm{lb} / \mathrm{sec}$ was passed through the control drum for about $75 \mathrm{sec}$, followed by a flow ramp of about $0.22 \mathrm{lb} / \mathrm{sec}^{2}$ for $43 \mathrm{sec}$ (see Figure 10). The inlet piping was not prechilled before the run. The maximum bow of about $0.0135 \mathrm{in}$. was measured about $15 \mathrm{sec}$ after the start of the $0.22 \mathrm{lb} / \mathrm{sec}^{2}$ ramp. The maximum $\Delta T$ was about $70^{\circ} \mathrm{R}$. It can be seen that a bow existed at the start of the run, before any flow at all. This value is about $0.0025 \mathrm{in}$. and is in the opposite direction to the main thermat gradient bow. It is probably due to clearance in the bearings and a slight manufacturing bow in the drum. 
RUN 8

This run was the most severe ramp applied during these tests (see Figure 11). The ramp is about $5.0 \mathrm{lb} / \mathrm{sec}^{2}$ for $5 \mathrm{sec}$ followed by a drop-off in flow to $20 \mathrm{lb} / \mathrm{sec}$ in another $10 \mathrm{sec}$. The inlet temperature starts at $270^{\circ} \mathrm{R}$ and drops to $145^{\circ} \mathrm{R}$ in 6 sec. The maximum measured bow was $0.038 \mathrm{in}$. and the maximum $\Delta T$ was $152^{\circ} \mathrm{R}$.

RUN 9

The flow profile for this run consists of a steady prechill flow of $2.0 \mathrm{lb} / \mathrm{sec}$ for $60 \mathrm{sec}$ followed by a flow ramp of about $1.38 \mathrm{lb} / \mathrm{sec}^{2}$ for $13 \mathrm{sec}$ (see Figure 12). The bow undergoes two maxima. The first one is $0.0165 \mathrm{in}$. at $t=35 \mathrm{sec}$, after which the bow drops to $0.012 \mathrm{in}$. at $t=60 \mathrm{sec}$. The second maximum occurs during the $1.38 \mathrm{lb} / \mathrm{sec}^{2} \mathrm{ramp}$ at $t=$ $70 \mathrm{sec}$, and is equal to $0.0175 \mathrm{in}$. The corresponding $\Delta T$ values are $65^{\circ}$ and $106^{\circ} \mathrm{R}$. It is seen that the prechill flow served to markedly reduce the maximum bow. After the prechill, a $1.38 \mathrm{lb} / \mathrm{sec}^{2}$ flow ramp produced only $0.0175 \mathrm{in.} \mathrm{maximum} \mathrm{bow,} \mathrm{while} \mathrm{in} \mathrm{Run} 5$ (see Figure 8), where there was no prechill, a $0.95 \mathrm{lb} / \mathrm{sec}^{2}$ flow ramp produced $0.031 \mathrm{in}$. maximum bow.

RUN 10

For this run, a $30 \mathrm{sec}$ flow of $2.0 \mathrm{lb} / \mathrm{sec}$ was followed by a ramp of about $1.50 \mathrm{lb} / \mathrm{sec}^{2}$ (see Figure 13). The maximum bow occurs during the ramp and is equal to $0.031 \mathrm{in}$. The maximum $\Delta T$ is $150^{\circ} \mathrm{R}$. It is seen that the $30 \mathrm{sec}$ prechill flow is not nearly as effective in reducing bow as the $60 \mathrm{sec}$ prechill flow of Run 9. While the final flow ramps were fairly similar, the $30 \mathrm{sec}$ prechill allowed $0.031 \mathrm{in}$. maximum bow and the $60 \mathrm{sec}$ prechill only 0.0175 .

Figure 15 shows the measured bow plotted against the temperature difference across the drum at the center station. The maximum bow usually occurred at a slightly different time than the maximum $\Delta T$ measured at the center station. This indicates that the effective maximum $\Delta T$ across the entire drum and the maximum $\Delta T$ across the center station occur at 
different times. Figure 16 shows the measured bow plotted against a thermal expansion factor which includes the effects of both $\Delta T$ and the variation of coefficient of expansion with temperature. 


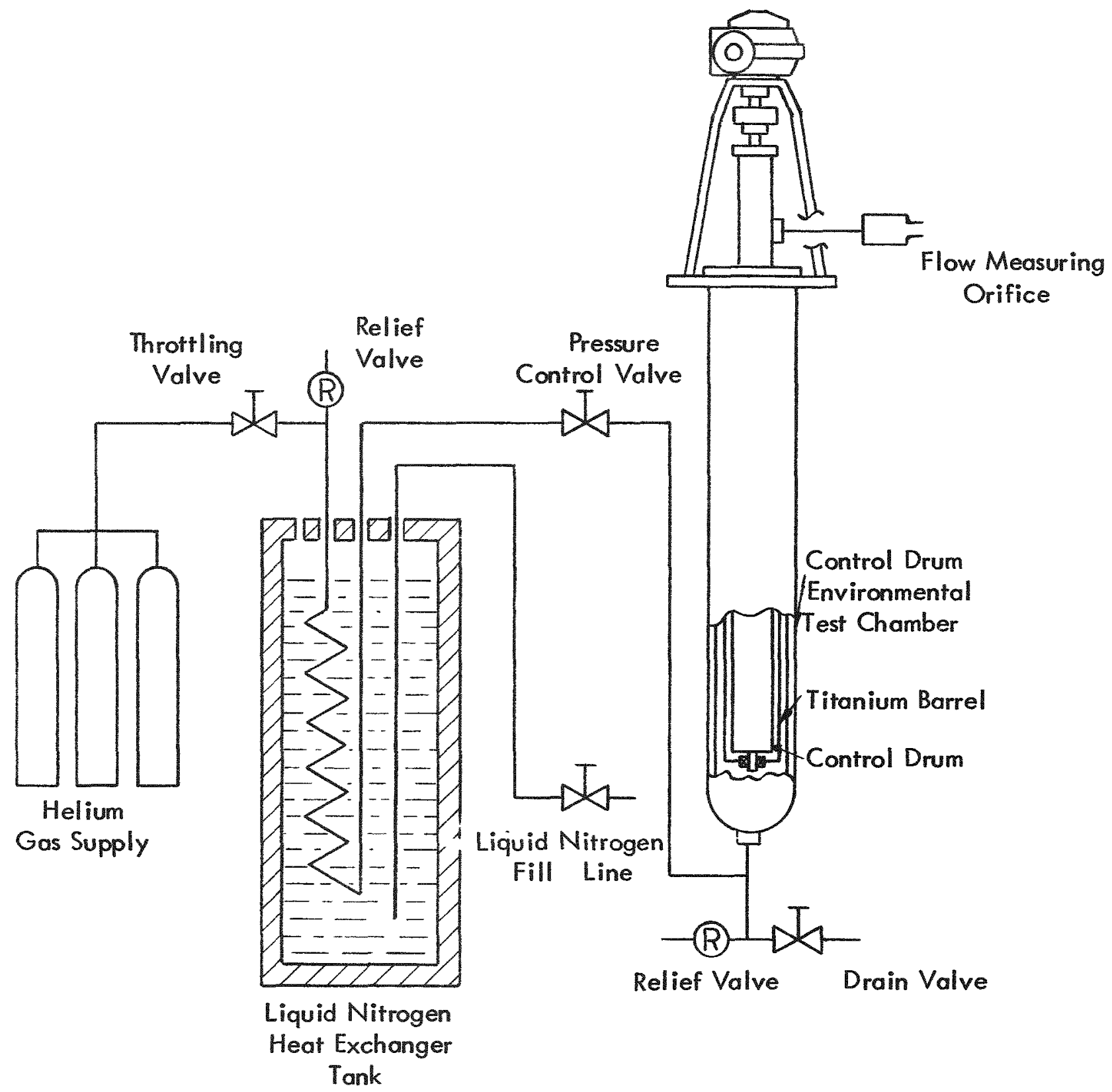

FIGURE

GAS SUPPLY SYSTEM FOR CONTROL DRUM BOW TEST 


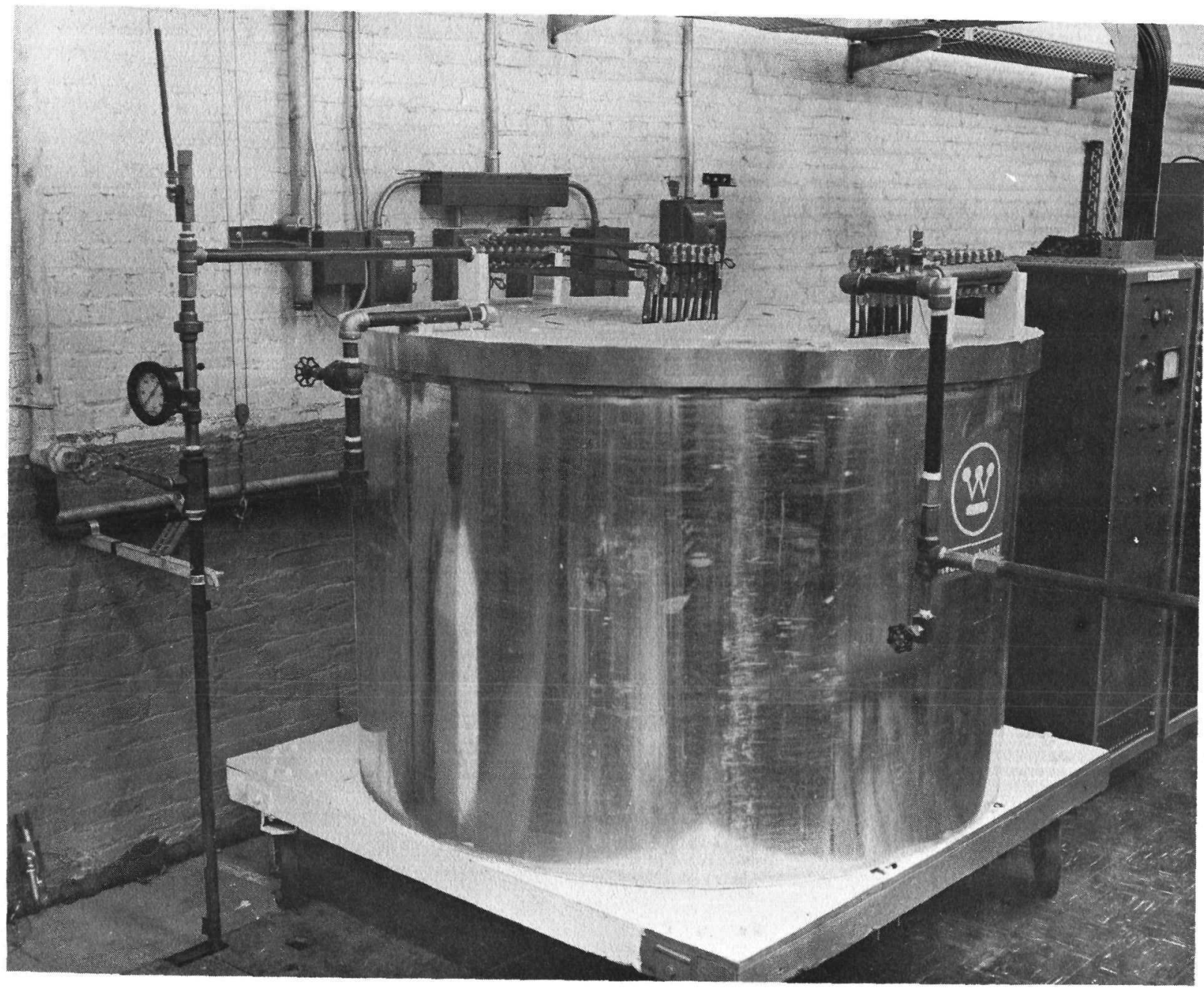

FIGURE 2

HEAT EXCHANGER TANK 


\section{(*) Stronuclear \\ WANL-TME-977}

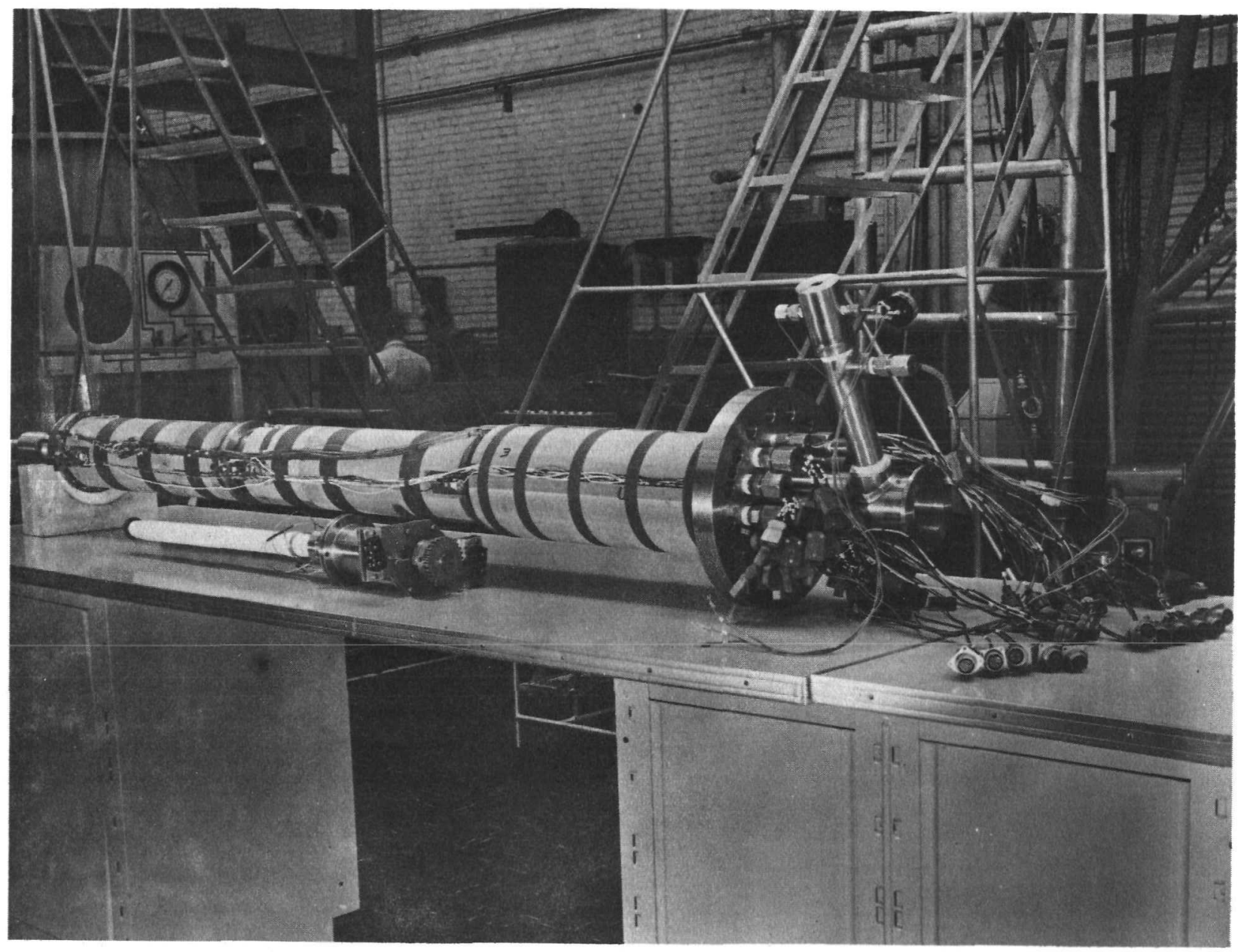

FIGURE 3

CONTROL DRUM TEST CYLINDER SHOWING

WOOD INSULATION, TORQUE SHAFT, FLOW MEASURING NOZZLE AND INSTRUMENTATION WIRING 
(w) Stronuclear

WANL-TME-977

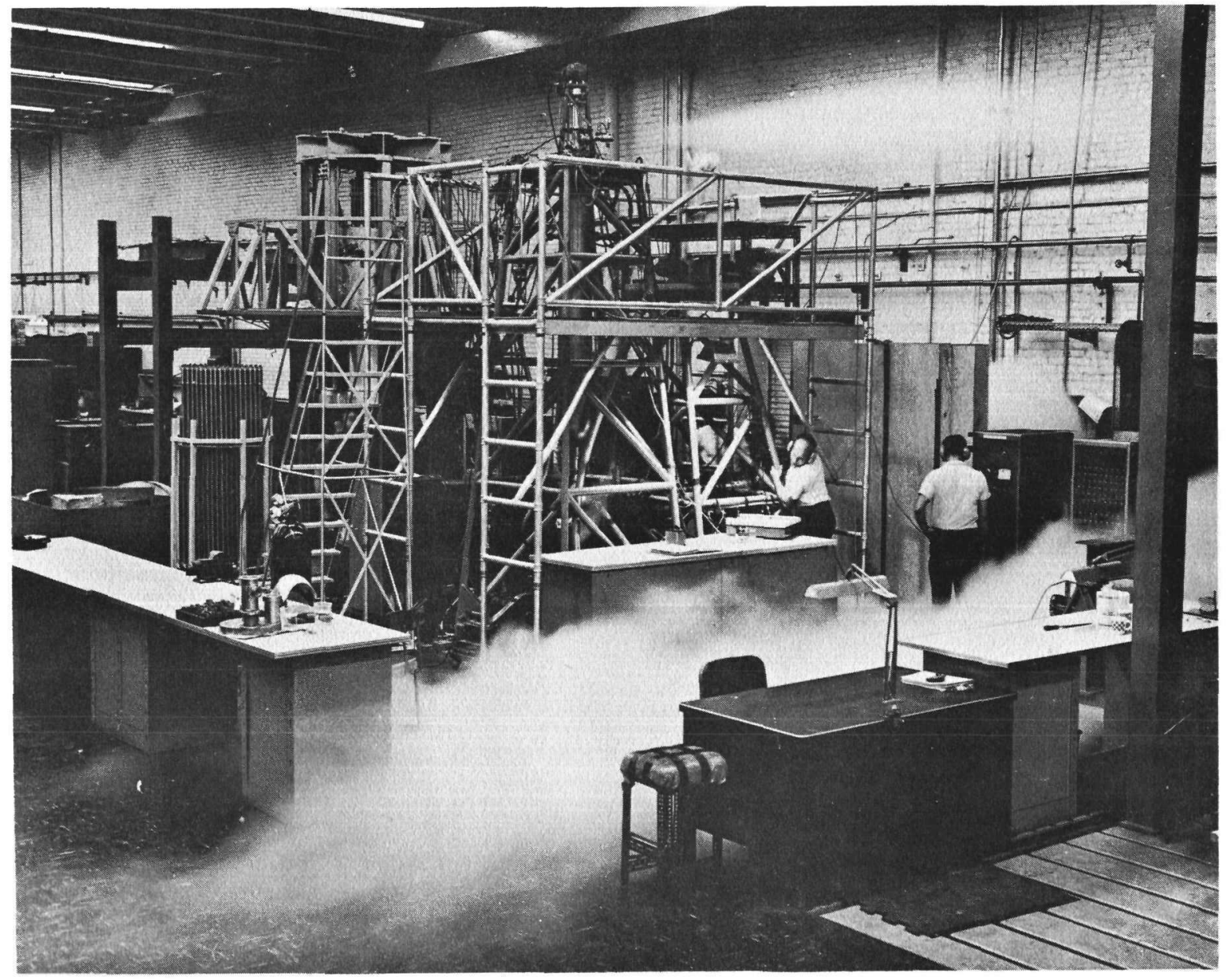

FIGURE 4

CONTROL DRUM BOW TEST IN OPERATION 
FLGURE 5 CONTROL DRUM BOW TEST RESULTS

RUN NO. 2

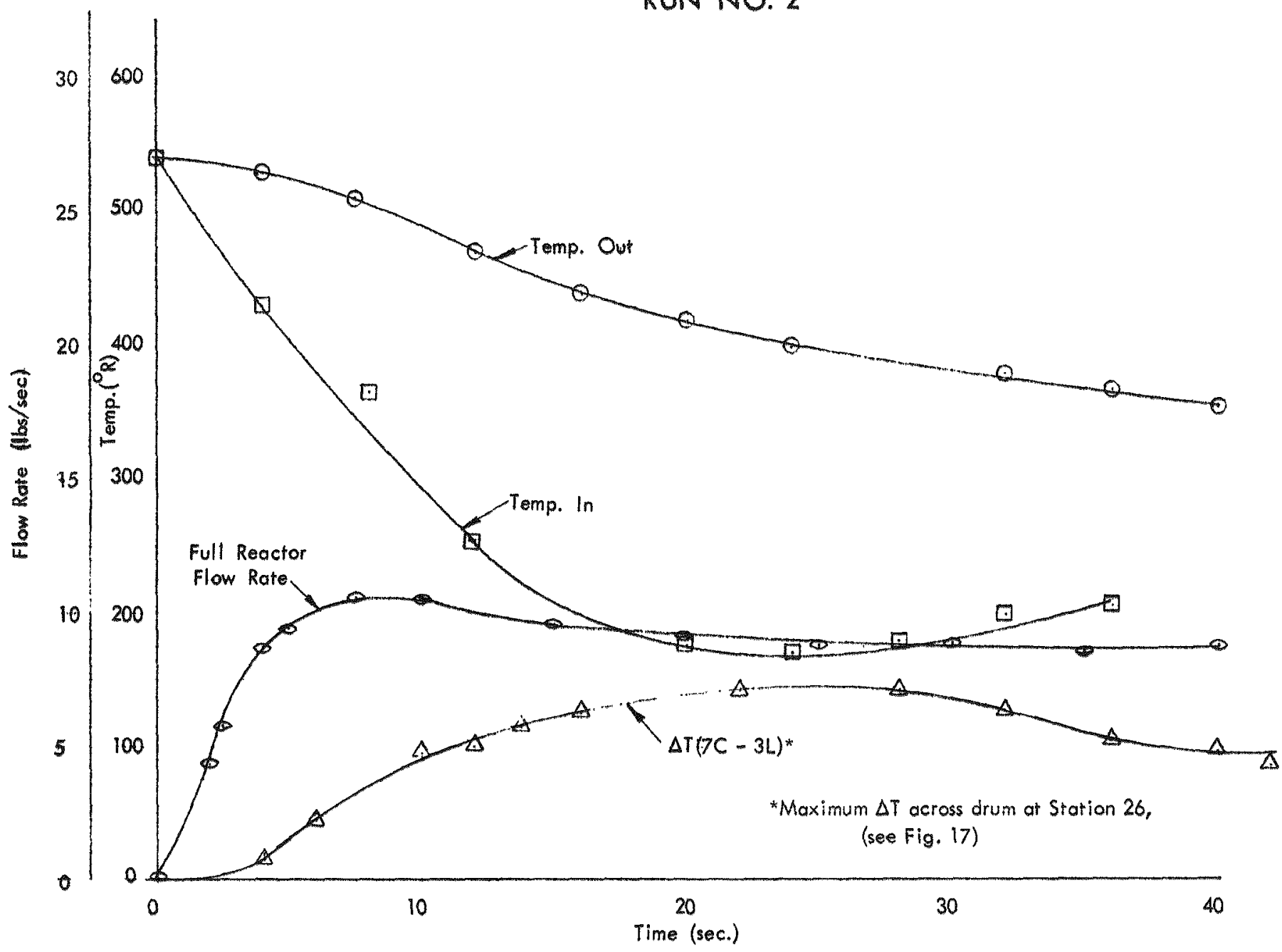




\section{FIGURE 6 CONTROL DRUM BOW TEST RESULTS}

RUN NO. 2

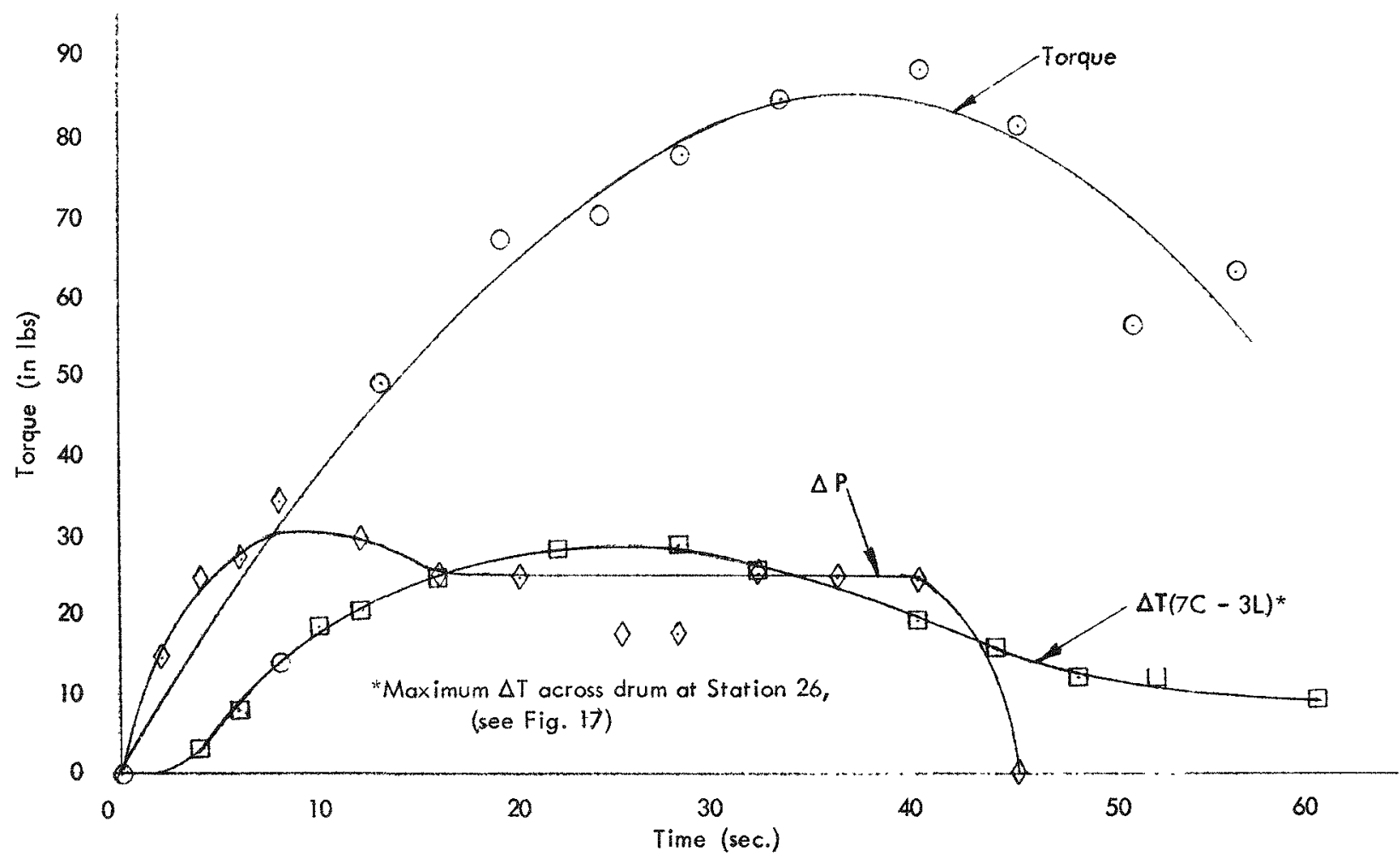



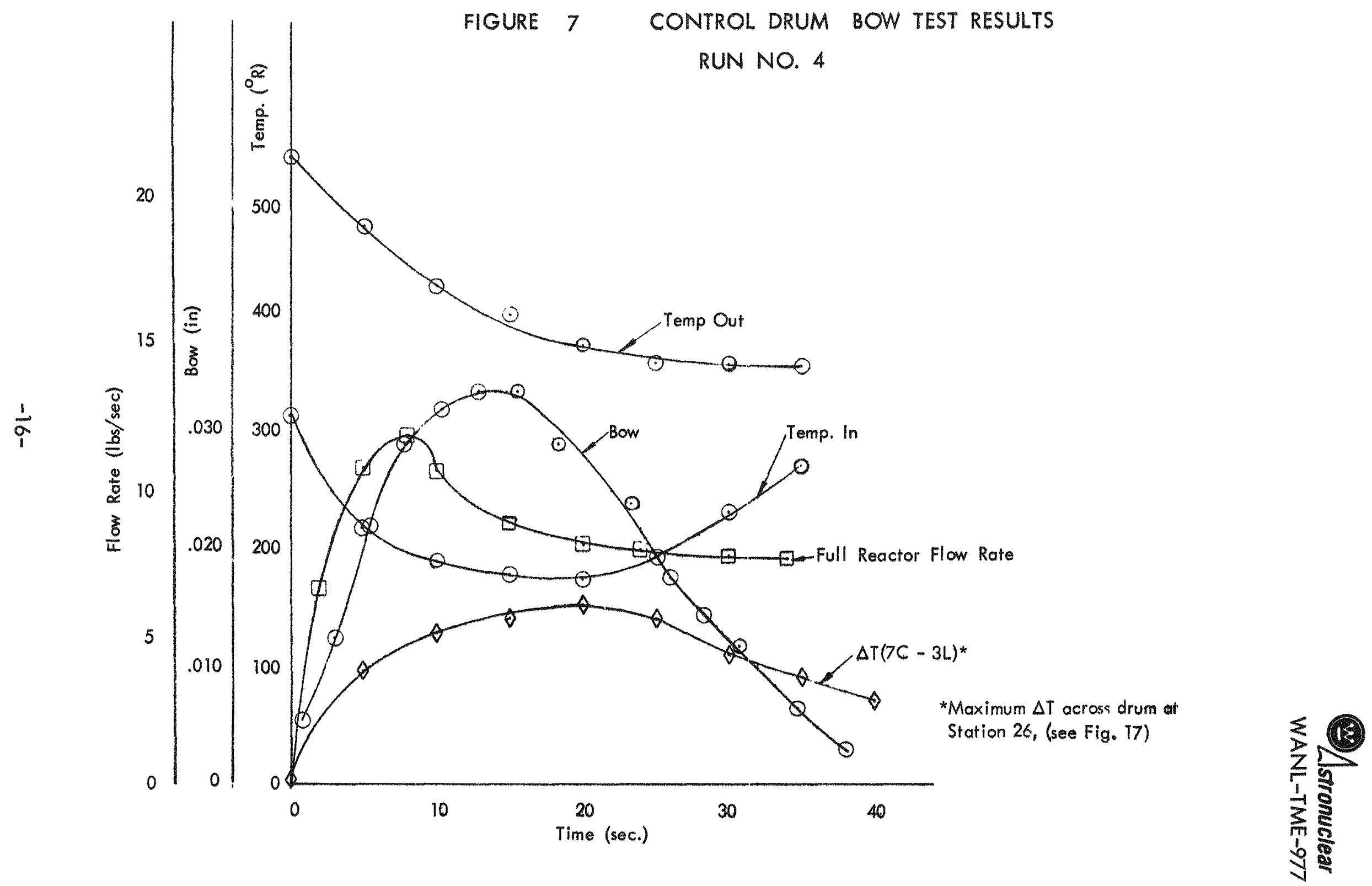


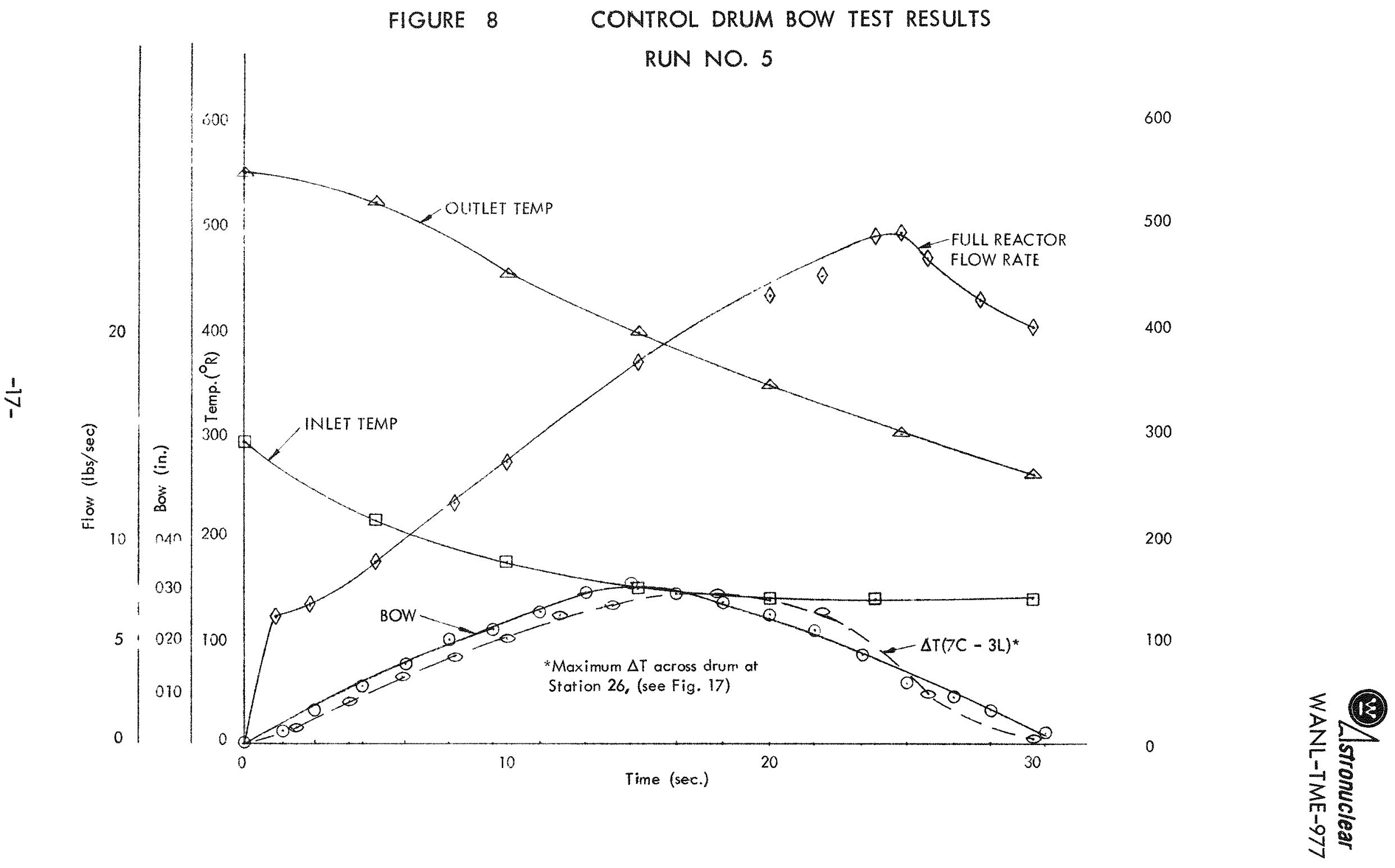



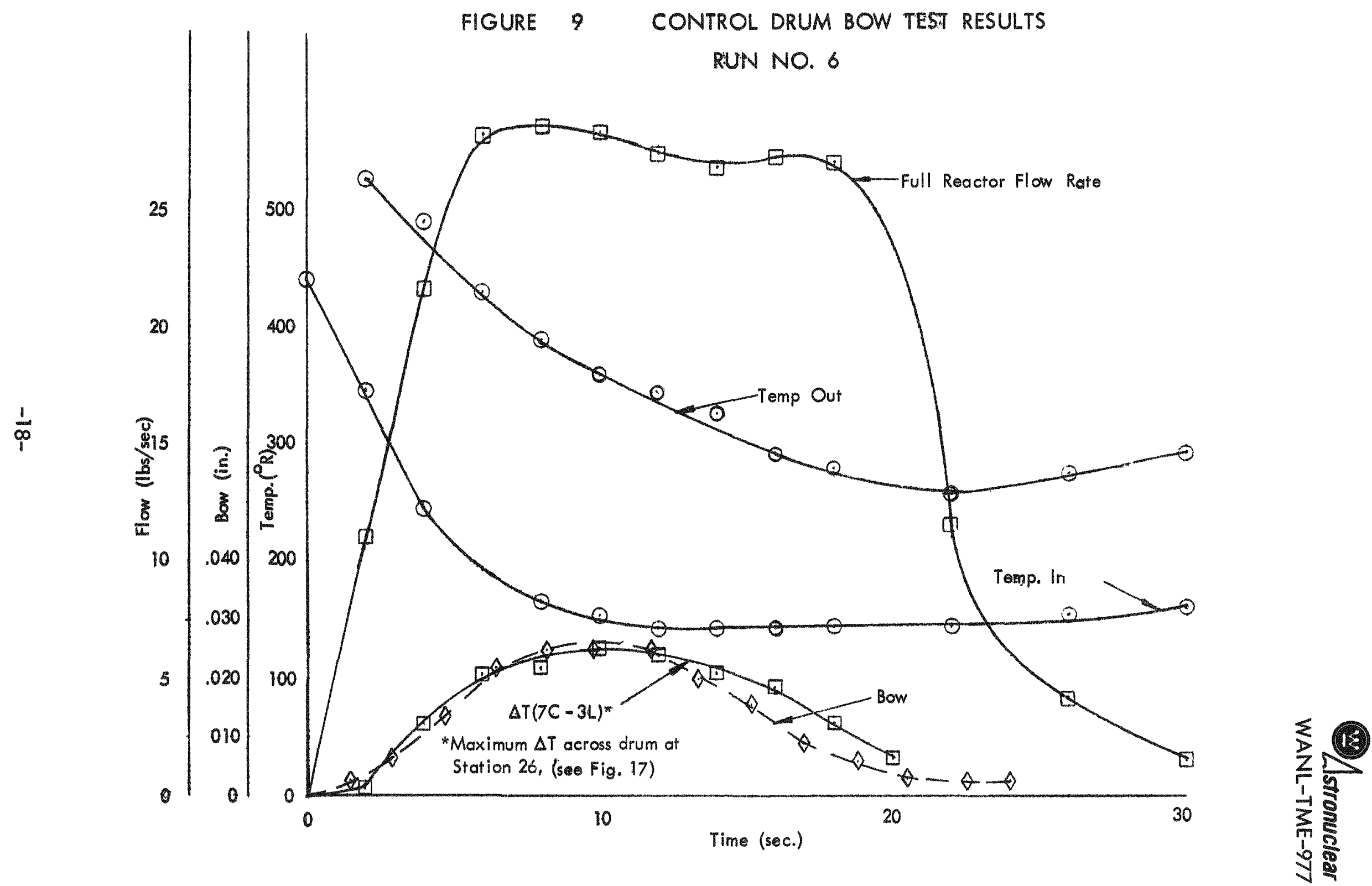


\section{FIGURE 10 CONTROL DRUM BOW TEST RESULTS}

RUN NO. 7

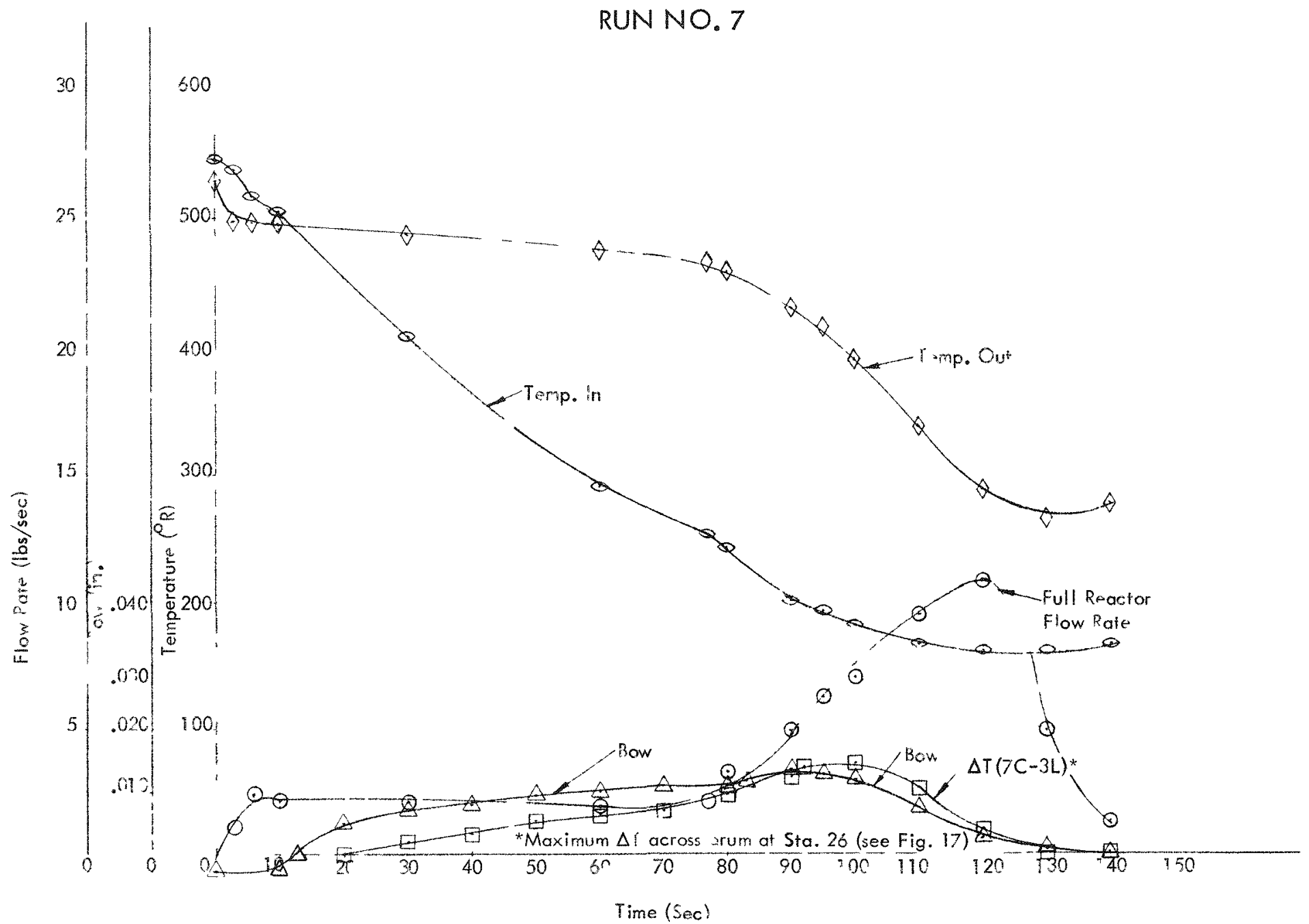



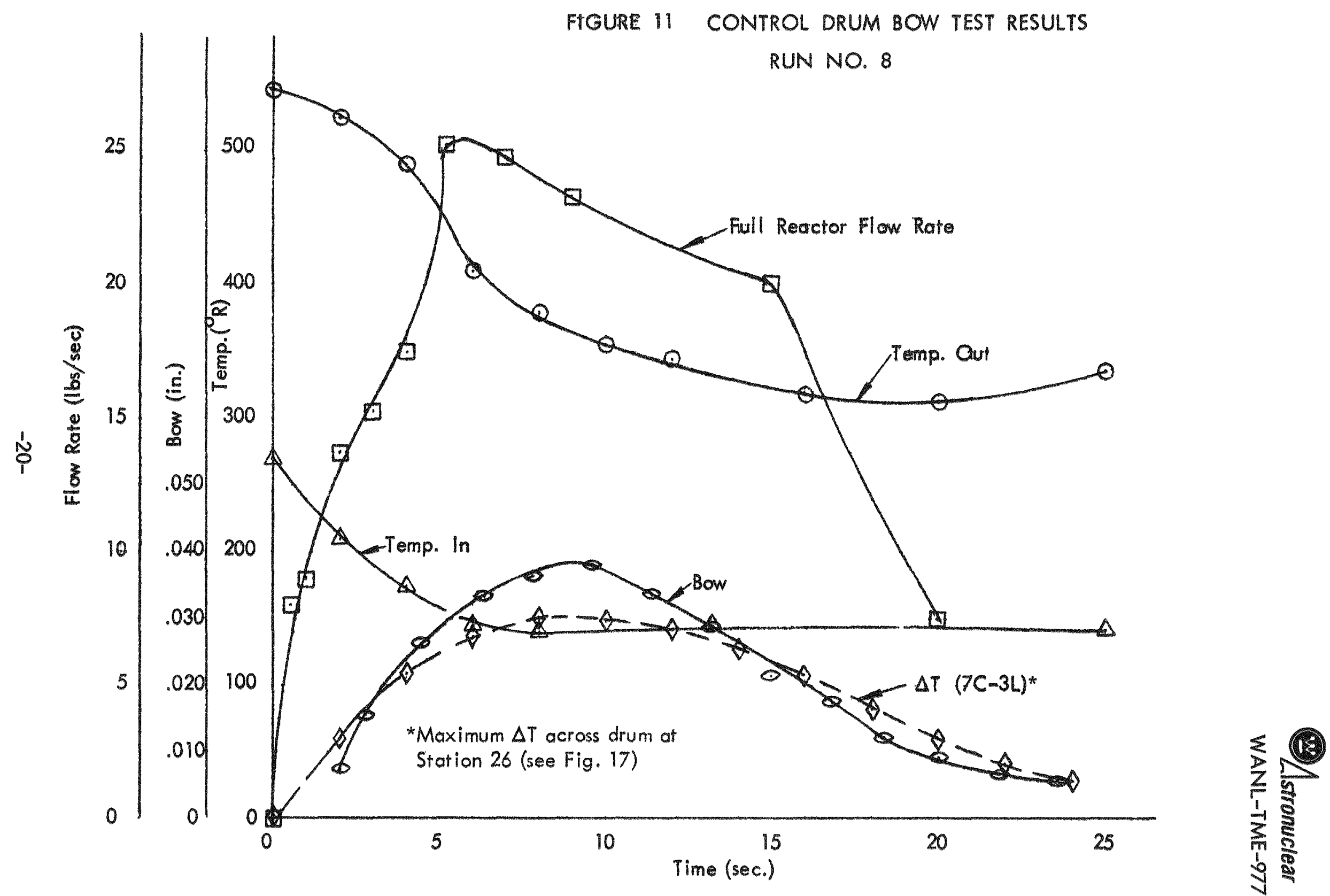
FIGURE. 12 CONTROL DRUM BOW TEST RESULTS

RUN NO. 9

$\frac{1}{1}$

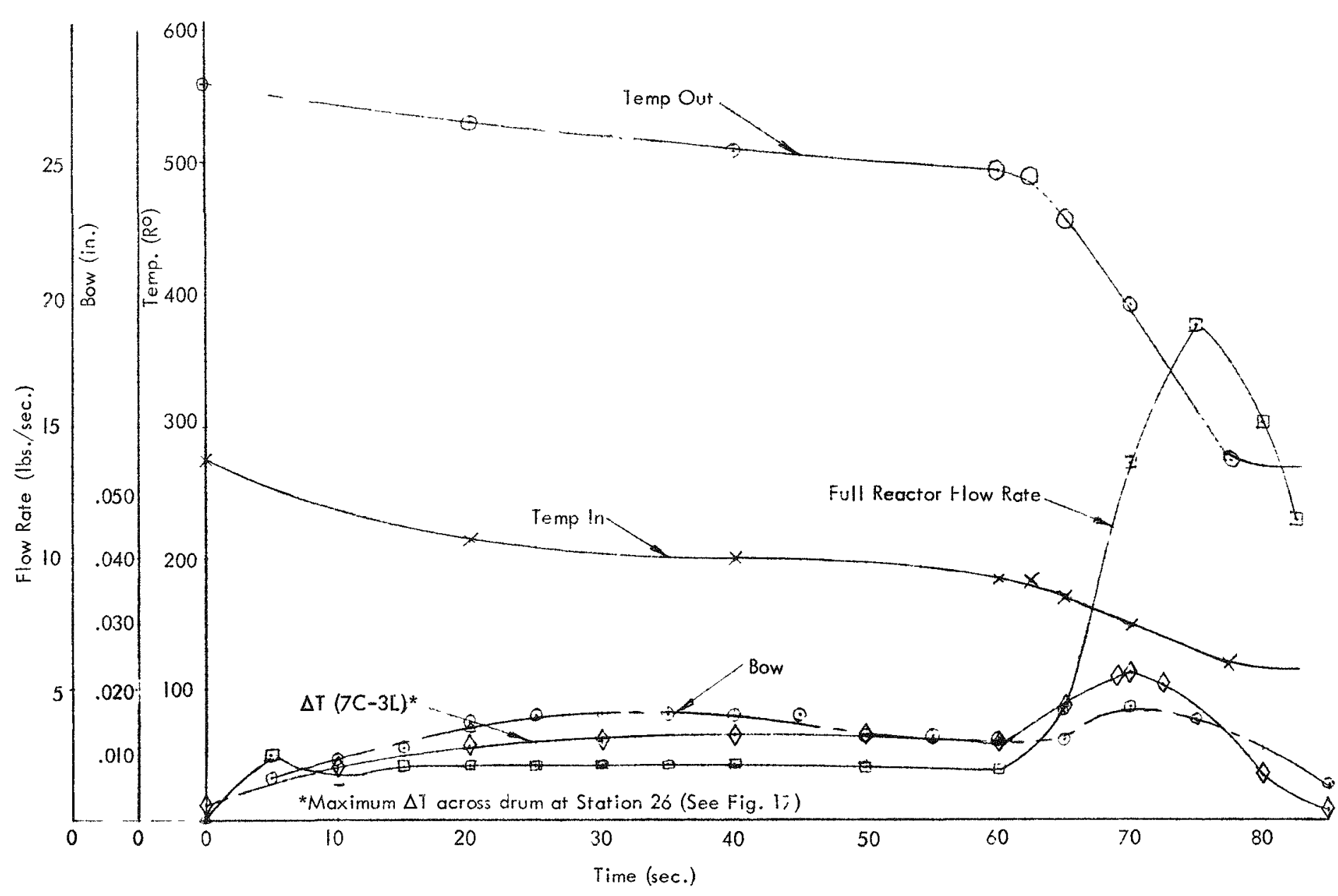


FIGURE 13 CONTROL DRUM BOW TEST RESULTS
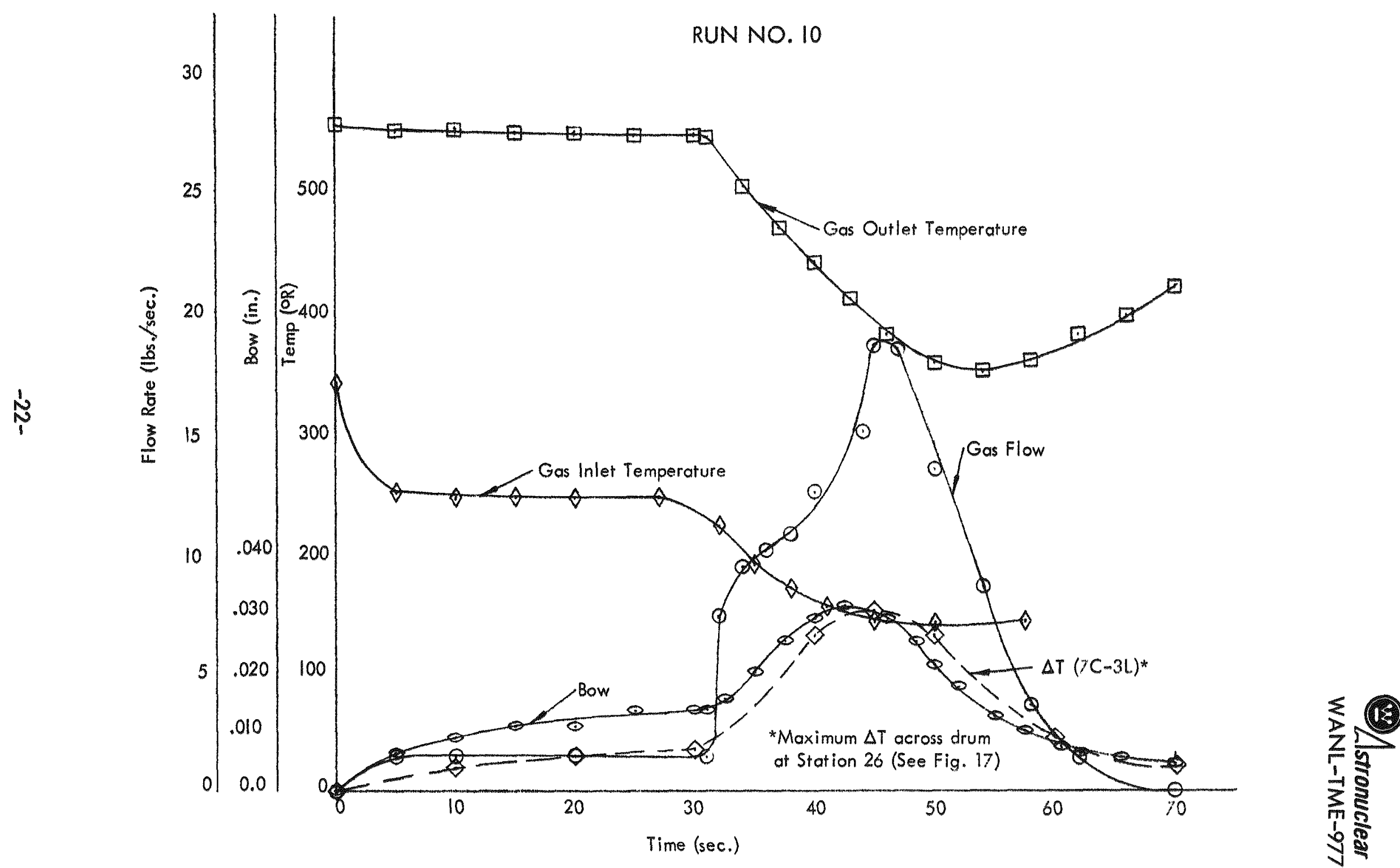


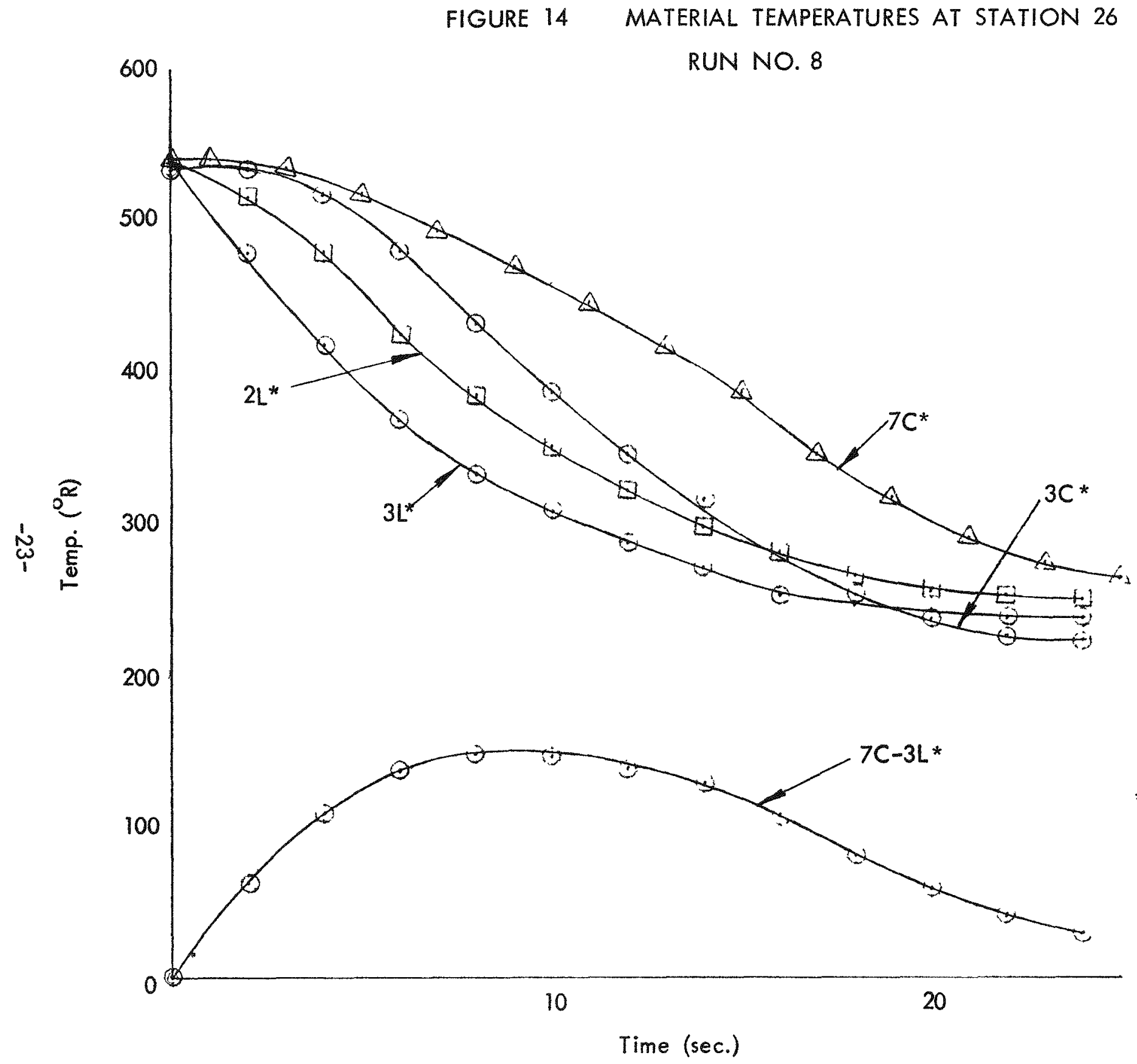

*See Figure 17 for

Thermocouple Locations

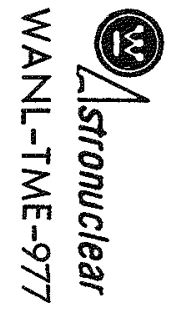


FIGURE 15 MEASURED DRUM BOW VS TEMPERATURE DIFFERENCE

ACROSS DRUM AT CENTER STATION (STA. 26)

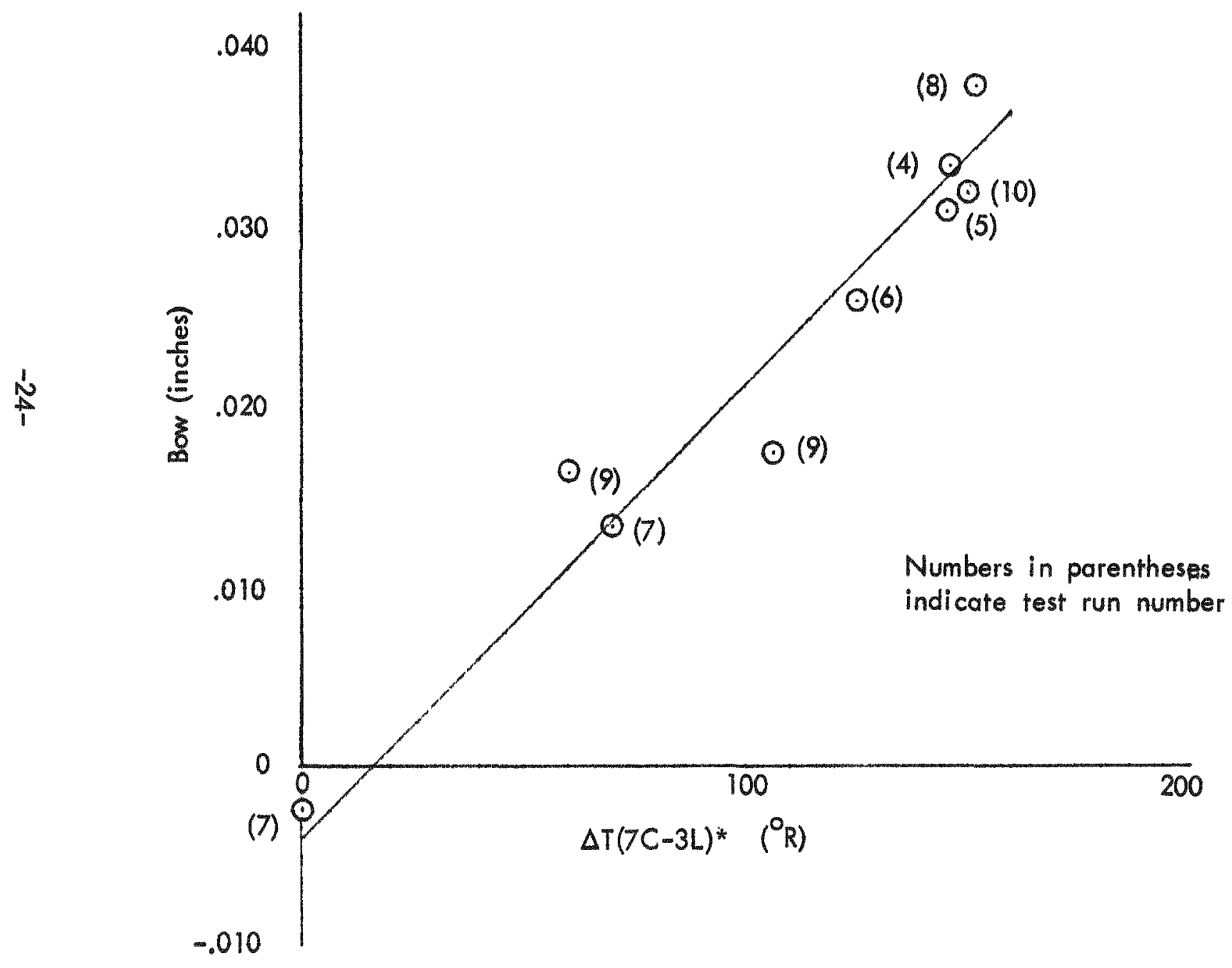

* See Figure 17 for Thermocouple Locations 
FIGURE 16 MEASURED DRUM BOW VS DIFFERENTIAL THERMAL EXPANSION FACTOR AT DRUM CENTER STATION

(STA. 26)

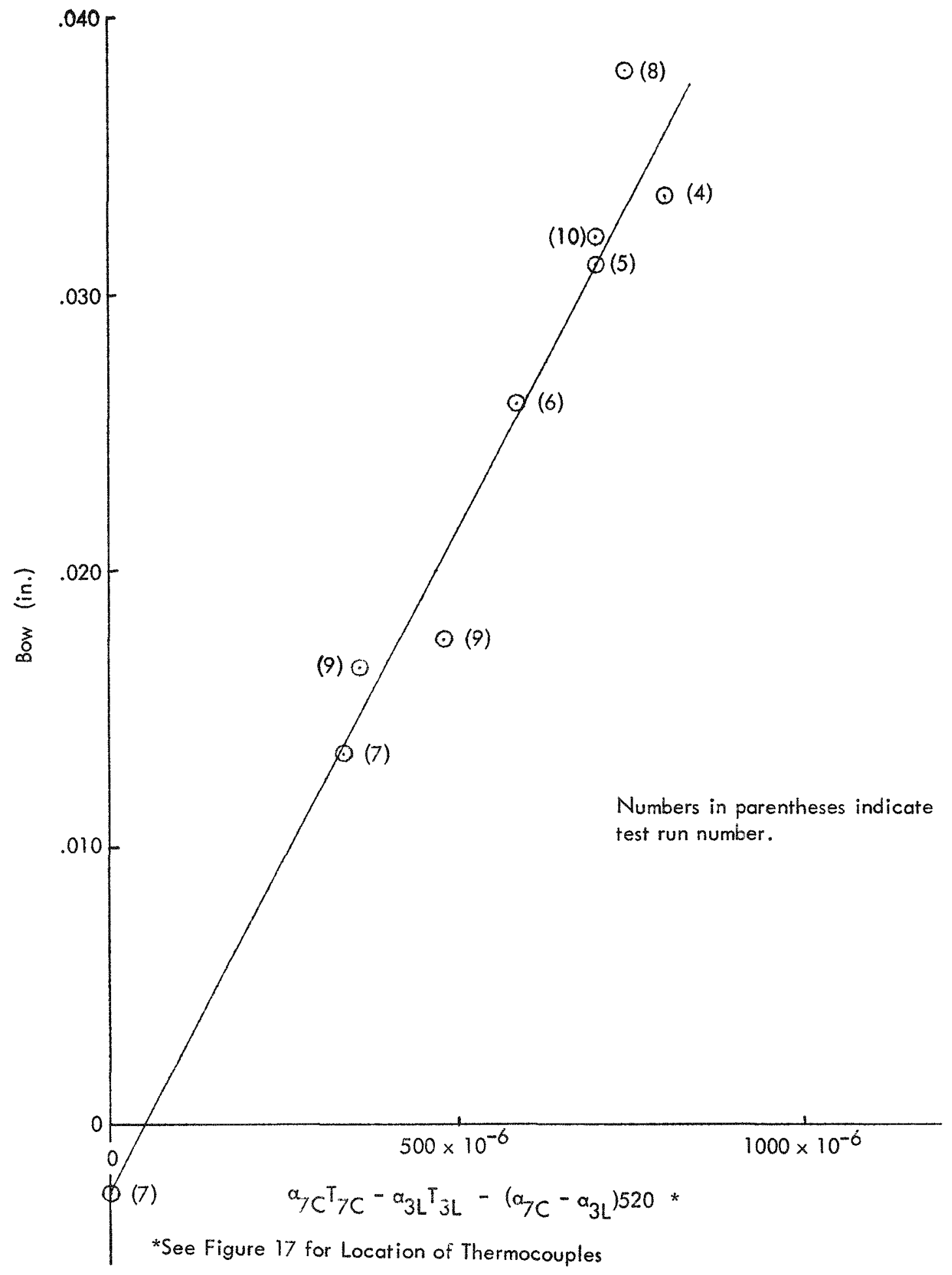




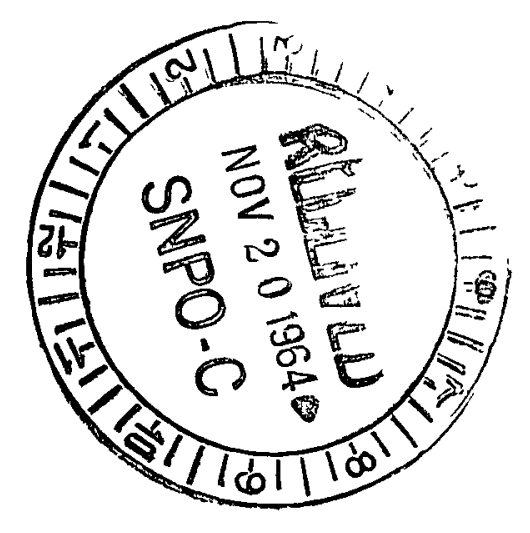

